\title{
Nemendamiðað námsumhverfi: Hugmyndir framhaldsskólanemenda um kjöraðstæður til náms
}

\author{
Anna Kristín Sigurðardóttir og Sigrún Harpa Magnúsdóttir
}

\begin{abstract}
Um höfundana $>$ About the authors $>$ Heimildir
Í pessari rannsókn er leitast við að varpa ljósi á hugmyndir framhaldsskólanemenda um kjöraðstæður til náms samanborið við pær aðstæður sem peir búa við og möguleika peirra til að hafa áhrifpará. Áhrif nemenda á eigið námsumhverfi tengjast hugmyndum um nemendamiðað nám og peim er meðal annars ætlað að efla skuldbindingu nemenda gagnvart skólastarfinu. Gögnum var safnað í níu framhaldsskólum með viðtölum, vettvangsathugunum í skólastofum og ljósmyndum. Tekin voru hópviðtöl við nemendur og peir beðnir að forgangsraða myndum af ýmsum aðstæðum í skóla með hliðsjón af pví hvernig pær hentuðu við nám að peirra mati. Niðurstöður úr peirri umræðu voru bornar saman við aðstæður eins og pær birtust rannsakendum í skólastofunni. Helstu niðurstöður benda til pess að algengast sé að í kennslustundum sitji nemendur við einstaklingsborð í röðum par sem allir snúa andliti í sömu átt, vel pekktar aðstæður 1 íslensku skólaumhverfi. Nemendum fannst aftur á móti best að læra í umhverfi par sem peir hefðu einhvers konar svigrúm, til dæmis val um pað hvort peir ynnu sjálfstætt eða með öðrum. Deir kusu síður námsumhverfi sem var í föstum skorðum og gerði ráð fyrir einhæfum námsaðferðum, eins og algengast var í pátttökuskólunum. Рað er von höfunda að niðurstöðurnar megi hafa til hliðsjónar við að hanna og bæta námsumhverfi nemenda með aukinni áherslu á lýðræðislega pátttöku peirra og möguleika til að hafa áhrif á aðstæður sínar. Vísbendingar eru úr öðrum rannsóknum um að slíkt geti eflt skuldbindingu peirra gagnvart náminu og par með hugsanlega dregið úr brotthvarfi.
\end{abstract}

Efnisorđ: Námsumhverfi, Tígulaðferð, Nemendamiðað nám, Skuldbinding nemenda, Framhaldsskóli,

\section{Inngangur}

Viðfangsefni pessarar greinar er hið ápreifanlega eða manngerða námsumhverfi (e. physical learning environment) 1 framhaldsskólum út frá sjónarhóli nemenda. Með námsumhverfi er átt við hönnun húsnæðis, húsbúnað, tæki og annað pað sem mótar umhverfið í skólanum par sem nemendur læra. Á hugi rannsakenda sem hafa fjallað um námsumhverfi hin seinni ár hefur einkum beinst að pví að skoða hvort og pá hvernig umhverfið hefur áhrif á nám og kennslu. Markmið pessarar rannsóknar er að varpa ljósi á hugmyndir nemenda í íslenskum framhaldsskólum um kjöraðstæður til náms og möguleika peirra til að hafa áhrif par á. Niðurstöður eru skoðaðar út frá kenningum um nemendamiðað nám (Land, Hannafin og Oliver, 2012) sem getur eflt skuldbindingu (e. engagement) nemenda gagnvart skólaverkefnum (Fredricks, Blumenfeld og Paris, 2004) og gæti mögulega dregið úr líkum á brotthvarfi nemenda, en pað hefur verið umtalsvert í íslenskum framhaldsskólum (sjá til dæmis Mennta-og menningarmálaráðuneytið, 2014). Spurningarnar, sem leitað er svara við, eru eftirfarandi: 
a) Hverjar eru hugmyndir nemenda um gott námsumhverfi og hvernig samræmast pær raunverulegum aðstæðum í framhaldsskólum?

b) Telja nemendur sig geta haft áhrif á námsumhverfi eða pær aðstæður sem peir læra við?

\section{Nemendamiðað nám}

Niðurstöður rannsókna á grunnskólum hér á landi benda til pess að hugmyndir nemenda hafi ekki mikið vægi í skipulagi námsins (Rúnar Sigpórsson, Anna-Lind Pétursdóttir og Póra Björk Jónsdóttir, 2014) og vísbendingar eru um að pessu sé svipað farið í framhaldsskólum (Gerður G. Óskarsdóttir, 2012) pótt minna sé um pað vitað. Petta er svo, prátt fyrir skýr ákvæði í lögum um skyldur skóla til að bjóða „hverjum nemanda upp á nám við hæfi““ (lög um framhaldsskóla, nr. 92/2008, 2. gr.). Í lögunum (nr. 92/2008) er kveðið á um rétt nemenda til að hafa áhrif en par segir meðal annars í 33. gr.:

Allir nemendur eiga rétt á kennslu við sitt hæfi í hvetjandi námsumhverfi í viðeigandi húsnæði sem tekur mið af pörfum peirra.... Nemendur eiga rétt á pví að koma á framfæri sjónarmiðum sínum varðandi námsumhverfi, námstilhögun, fyrirkomulag skólastarfs og aðrar ákvarðanir sem snerta pá. Taka skal tillit til sjónarmiða peirra eins og unnt er.

Hugmyndir um nemendamiðað nám grundvallast á kenningum hugsmíðahyggju par sem litið er á virka pátttöku sem meginforsendu pess að nám fari fram (Land o.fl., 2012). Nemandinn byggir upp sinn eigin skilning og pekkingu með virkri pátttöku í mótun námsins, par með talið með pví að hafa áhrif á aðstæður og námsumhverfi. Til að koma pessu við parf skipulag daglegs starfs í skólanum að vera pað sveigjanlegt að hver og einn nemandi geti haft áhrif á eigin aðstæður, vinnubrögð og viðfangsefni. Smit, Brabander og Martens (2014) sýndu fram á að nemendur sem boðið var upp á slíkan sveigjanleika töldu sig hafa meira sjálfræði (e. autonomy) um námið og sýndu pví meiri áhuga. Fjölmargar rannsóknir hafa sýnt fram á tengsl sjálfræðis og áhuga við skuldbindingu og vellíðan í skóla (Blackmore, Bateman, Loughlin, O’Mara og Aranda, 2011; Fredricks o.fl., 2004; Fullan, 2016; Greene, Miller, Crowson, Duke og Akey, 2004; Prain o.fl., 2015; Tanner, 2008). Nýleg rannsókn meðal íslenskra framhaldsskólanema leiddi í ljós tengsl milli skorts á skuldbindingu (e. disengagement) og hættu á brotthvarfi (Kristjana Stella Blöndal og Sigrún Aðalbjarnardóttir, 2012), sem rímar vel við pær niðurstöður Kanevsky og Keighley (2003) að nemendur sem telja að ekki sé hlustað á pá hafi tilhneigingu til að leiðast í skólanum.

Hugmyndir um nemendamiðað nám hafa verið í kreiki í skólaumræðu hér á landi og erlendis um nokkurt skeið, einkum hvað varðar grunnskólann. Pær hafa meðal annars birst í stefnuskjölum og gengið undir ýmsum heitum (Anna Kristín Sigurðardóttir, 2007; Ingvar Sigurgeirsson, 2005) en áhrif peirra á skólastarfið virðast víða hafa verið minni en til stóð (Gerður G. Óskarsdóttir, 2014).

\section{Tengsl ytra umhverfis við nám og kennslu}

Tiltölulega lítil vitneskja liggur fyrir um tengsl ytra umhverfis, kennsluhátta og náms nemenda (Blackmore o.fl., 2011; Gislason, 2010; Woolner, McCarter, Wall og Higgins, 2012). Margar af fyrirliggjandi rannsóknum beinast gjarna að takmörkuðum páttum og erfitt er að draga af peim almennar ályktanir pó margt megi af peim læra. Í niðurstöðum peirra birtist iðulega áhersla á tækni og fjölbreytt og sveigjanlegt umhverfi sem skapar meðal annars svigrúm fyrir einstaklingsbundið val (Benade, 2015; Blackmore o.fl., 2011; Woolner o.fl., 2012). Petta birtist til dæmis skýrt í niðurstöðum Mulcahy, Cleveland og Aberton (2015), sem ræddu við nemendur í framhaldsskólum í Ástralíu sem höfðu fengið nýtt og opið skólaumhverfi. Viðmælendur peirra kunnu vel að meta pað að geta sjálfir ráðið pví við hvaða aðstæður peir lærðu og með hverjum. Deir vildu geta ráðfært sig við samnemendur eftir hentugleikum hverju sinni. 
Rýmislæsi (e. spatial literacy) vísar til skilnings á hinu manngerða umhverfi, p.e. hvernig pað er mótað af peim sem nota pað og hvernig pað mótar starfið sem par fer fram (Moore-Russo, Viglietti, Chiu og Bateman, 2013). Imms, Cleveland og Fisher (2016) beita pessu hugtaki í rannsóknum sínum á skólaumhverfi í Ástralíu og pau telja að kennarar mættu almennt vera betur læsir á umhverfi sitt. Dað birtist meðal annars í pví að peir sjái ekki alltaf hvort og pá hvernig peir geti mótað umhverfi skólastofunnar til að efla nám og kennslu. Detta gæti einnig verið tilfellið hér á landi. Kennarar sem tóku pátt í rannsókninni Starfshættir í grunnskólum virtust t.d. almennt ekki hafa sterkar skoðanir á námsumhverfinu í skólastofunni og höfðu tilhneigingu til að laga kennsluhætti sína að pví umhverfi sem peir gengu inn í fremur en að móta pað eftir eigin áherslum (Anna Kristín Sigurðardóttir, 2014).

Bæði hér á landi og víða í hinum vestræna heimi er löng hefð fyrir ríkjandi skipulagi í hönnun skólabygginga sem má lýsa pannig að skólastofum af svipaðri stærð er raðað meðfram gangi og innan hverrar stofu er einstaklingsborðum raðað pannig að allir nemendur snúi andliti að töflu og kennaraborði. Veloso, Marques og Duarte (2015) segja petta skipulag byggjast á gömlum og úreltum hugmyndum um nám, sem geri ráđ fyrir að nám sé línulegt ferli par sem kennari miðlar og nemandi tekur við. Slíkt fyrirkomulag endurspeglar einnig valdatengsl pess sem á eða hefur pekkinguna og miðlar henni og peirra sem taka við, nemendanna (Markus, 1993). Áhrifaleysi nemandans er augljóst við slíkar aðstæður og sá sveigjanleiki sem kallað er eftir er par ekki til staðar (Benade, 2015; Dane, 2016). Detta hefðbundna skipulag virðist einnig vera ríkjandi í íslenskum skólum, bæði í grunnskólum (Anna Kristín Sigurðardóttir, 2014) og í framhaldsskólum (Gerður G. Óskarsdóttir, 2012) prátt fyrir dæmi um annað (Anna Kristín Sigurðardóttir og Torfi Hjartarson, 2016; Ingvar Sigurgeirsson, Arnór Benónýsson, Hallur Birkir Reynisson, Jóhanna Eydís Dórarinsdóttir og Valgerður Gunnarsdóttir, 2008; Duríður Jóna Jóhannsdóttir, 2017).

Margt sem fellur undir nemendamiðað nám, svo sem val nemenda eða áhrif peirra á eigin námsferil, virðist ekki vera algengt í skólum hér á landi, hvorki í grunnskólum (Rúnar Sigpórsson o.fl., 2014) né í framhaldsskólum (Gerður G. Óskarsdóttir, 2012). Almennt virðist pó sem nemendamiðað nám sé algengara í svokölluðum opnum kennslustofum en í peim sem eru skipulagðar á hefðbundinn hátt og að pað sé algengara par sem kennarar vinna í teymum (Alterator og Deed, 2013; Mulachy o.fl., 2015; Anna Kristín Sigurðardóttir og Torfi Hjartarson, 2016). Dessi munur birtist einnig skýrt 1 áströlskum skólum (Prain o.fl., 2015) par sem opin rými reyndust styðja vel við einstaklingsmiðað nám (e. personalised learning) og stuðla að velllíðan nemenda. Í opnum skólum eru kennslustofur af mismunandi stærð sem pjóna misstórum hópum nemenda og svæði eru skipulögð fyrir ólík vinnubrögð. Sameiginleg rými eru gjarna ætluð til samvinnu.

Dað er mikill samhljómur meðal rannsakenda í menntavísindum um að gæði menntunar séu háð flóknu samspili margra ólíkra pátta (Barrett, Zhang, Moffat og Kobbacy, 2013; Blackmore o.fl., 2011; Gislason, 2010; Mulachy o.fl., 2015; OECD, 2013), svo sem námsumhverfis, kennsluhátta, nemendamenningar, stjónunarhátta og skipulags. Hér er einungis lítill hluti af pessu flókna samspili til umfjöllunar, pað er nemendamiðað námsumhverfi. Til útskýringar setja höfundar fram skýringarmynd (mynd 1) um pað hvernig nemendamiðað námsumhverfi geti mögulega stuðlað að aukinni skuldbindingu nemenda sem aftur geti leitt til betri árangurs og vellíðunar peirra og par með minna brotthvarfs. Skýringarmyndin byggist á niðurstöðum fyrri rannsókna og má pví líta á hana sem rök fyrir mikilvægi viðfangsefnisins.

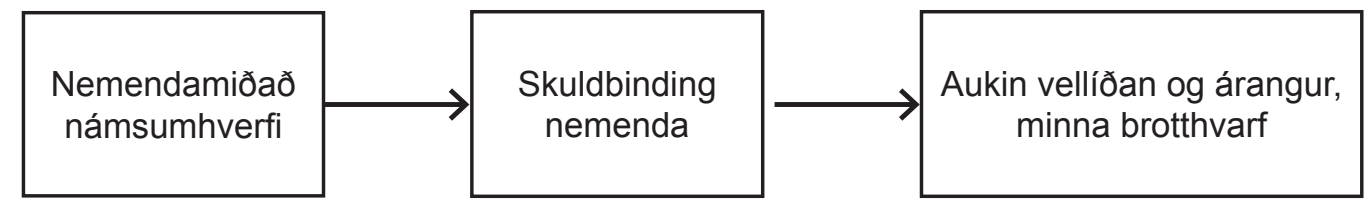

Mynd 1. Skýringarmynd um möguleg tengsl nemendamiðaðs námsumhverfis við vellíðan og árangur. 
Samkvæmt peim rannsóknum sem nefndar eru hér að framan er nemendamiðað námsumhverfi líklegt til að stuðla að aukinni skuldbindingu nemenda gagnvart náminu sem aftur er líkleg til að hafa jákvæð áhrif á árangur og líðan nemenda og gæti par með dregið úr brotthvarfi. Segja má að pessi rannsókn takmarkist einkum við fyrsta kassann á mynd 1, par sem reynt er að varpa ljósi á раð аð hvaða marki námsumhverfið í framhaldsskólum er nemendamiðað.

\section{Аðferð}

Rannsóknin sem hér er til umfjöllunar er hluti af rannsókninni Starfshættir í framhaldsskólum. [1] Í pessum hluta er unnið úr gögnum sem aflað var með hópviðtölum við nemendur og vettvangsathugunum í kennslustofum.

Leitað var eftir sjálfboðaliðum til pátttöku í viðtölunum úr hópi nemenda, sem allir voru að minnsta kosti 18 ára. Rætt var við 17 hópa og í hverjum hópi voru tveir til fimm nemendur, alls 56 nemendur, 30 stúlkur og 26 piltar. Helmingur nemenda sem komu í viðtal (50\%) voru af félags- og hugvísindabrautum, 23\% voru af raungreinabrautum, 14\% voru af starfsnámsbrautum, $9 \%$ af viðskipta- og hagfræðibraut og $4 \%$ voru af pverfaglegum brautum.

Í viðtölunum var stuðst við svokallaða tígulaðferð (Clark, 2012; Clark, Laing, Tiplady og Woolner, 2013), sem fólst í pví að pátttakendur fengu í hendur 12 myndir sem sýndu mismunandi námsaðstæður (tafla 1).

Tafla 1. Aðstæður til náms sem sýndar voru á myndunum tólf.

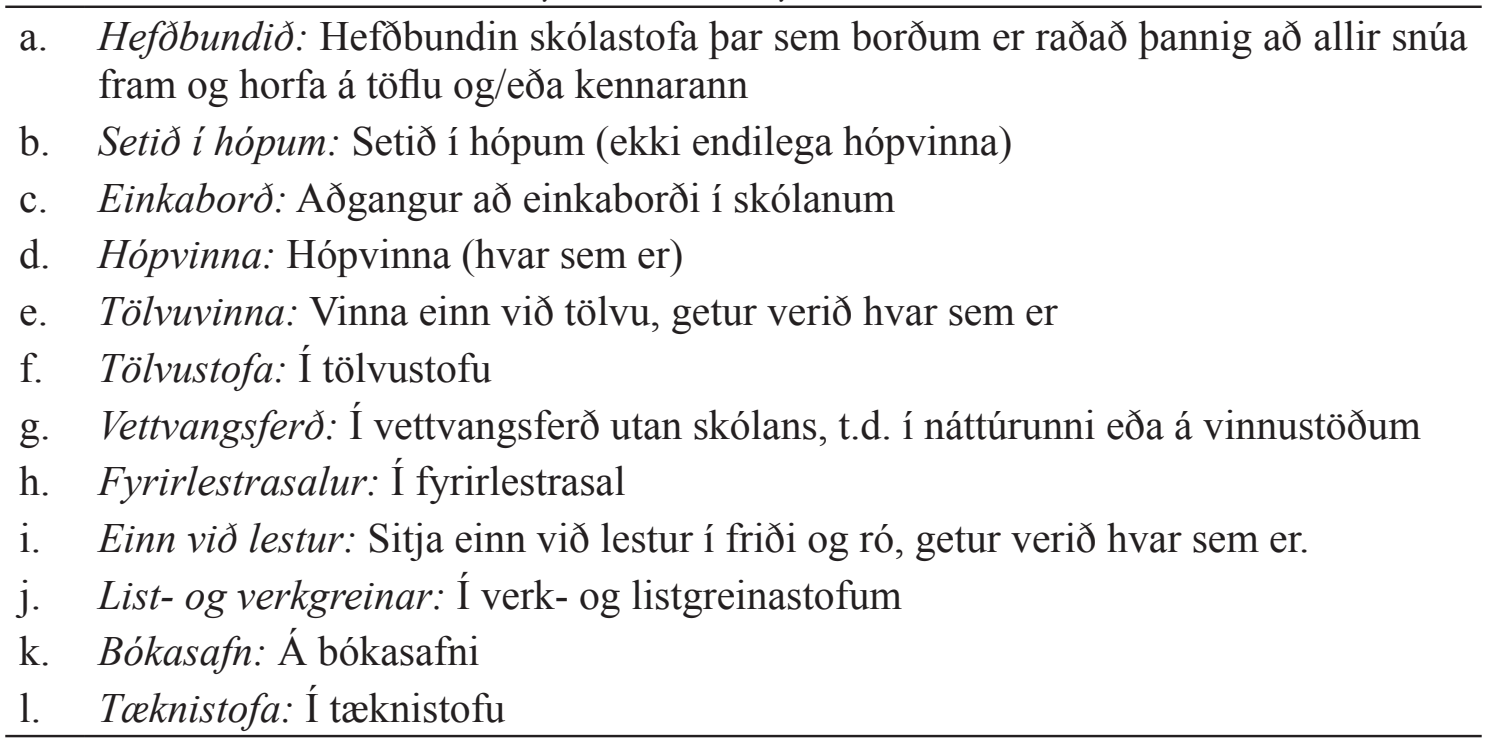

Nemendum var ætlað að komast að sameiginlegri niðurstöðu og velja níu myndir af 12 og raða í níu reiti (mynd 2) eftir pví hversu vel peim líkuðu viðkomandi aðstæður til náms. Dað sem peim líkaði best settu peir í efstu röðina (röð 1) en pað sem peim líkaði síst settu peir í neðstu röðina (röð 5) (sjá myndir 2 og 3). 


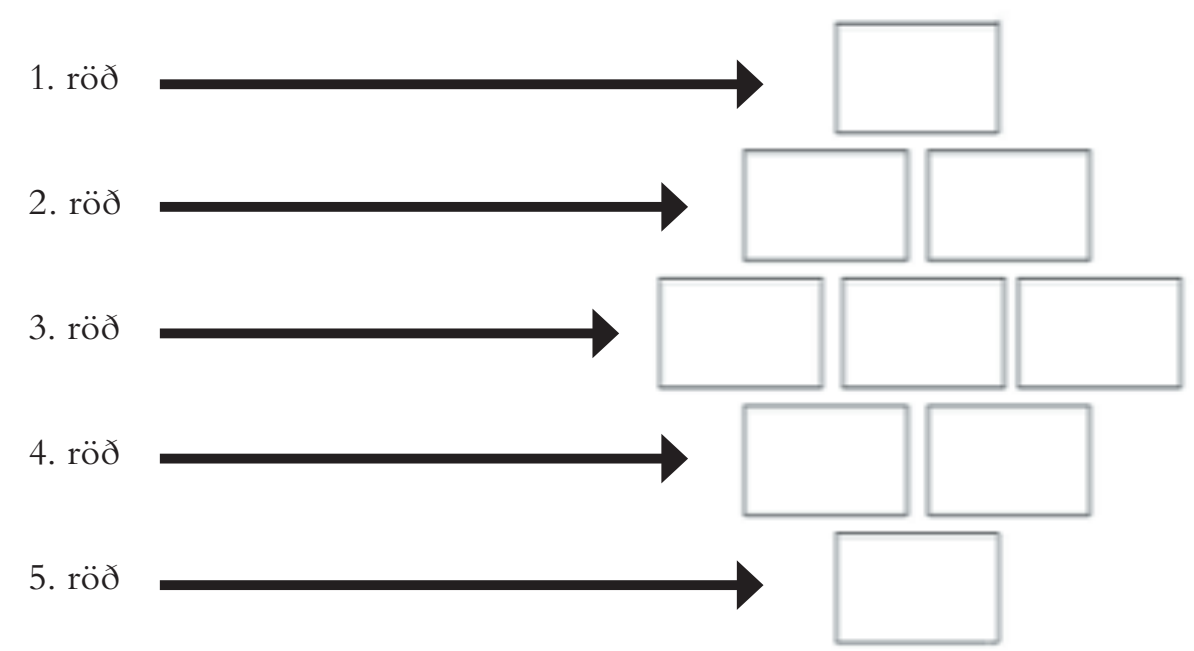

Mynd 2. Tígulform og raðir (Clark o.fl., 2013, bls. 6).

Pátttakendur röðuðu myndunum í forgangsröð á pappaspjald (stærð A3) sem búið var að teikna á reiti fyrir myndirnar níu, raðað í tígul (mynd 3). Efst á blaðinu stendur: Hér er gott að læra en neðst stendur: Hér er ekki gott að læra. Hópnum var ætlað að komast að sameiginlegri niðurstöðu um staðsetningu myndanna. Rannsakendur kölluðu eftir nánari útskýringum og rökum eftir bví sem peim fannst ástæða til en höfðu ekki önnur afskipti af samræðum nemenda. Umræðan var greind eftir myndunum og reynt að finna sameiginlega præði í umfjöllun um pær aðstæður sem annars vegar lentu ofarlega á tíglinum og hins vegar peim sem lentu neðarlega. Á mynd 3 má sjá dæmi um úrvinnslu eins nemendahóps.

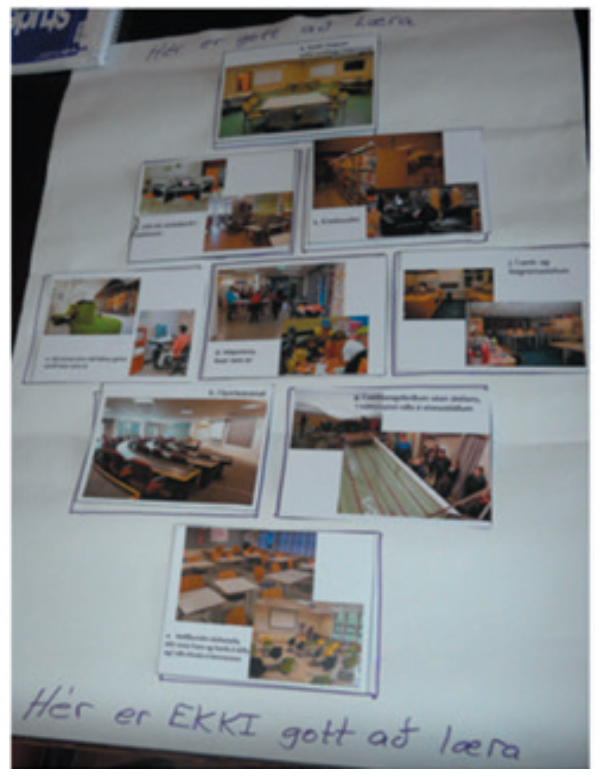

Mynd 2. Dæmi um uppröðun ljósmynda frá einum hópi.
Myndirnar voru teknar tilviljunarkennt af netinu og sýna pví ekki aðstæður sem nemendur bekkja í skólum sínum. Pær ná ekki yfir allar pær aðstæður sem eru til staðar í skólunum og takmarkast umræðan pví óhjákvæmilega við pað sem er á myndunum.

Vettvangsathugun var gerð í 130 kennslustundum sem voru valdar af handahófi og var dreift eins og unnt var á mismunandi námsgreinar og námsbrautir. Athugendur í rannsóknarteyminu skráđu nákvæmlega framvindu kennslustundarinnar og lýstu rýminu vandlega, pað er skipulagi, uppröðun húsgagna, efni á veggjum, búnaði, fjölda nemenda og fleira sem peim pótti skipta máli. Auk pess voru teknar ljósmyndir.

Við greiningu voru kennslustundirnar flokkaðar í fjóra meginflokka eftir skipulagi húsgagna í stofunni (tafla 2). 
Tafla 2. Kennslurými sem voru heimsótt og gerð peirra.

\begin{tabular}{llll}
\hline 1 & Borð og stólar í röđum pvert yfir stofu, allir snúa í sömu átt. & 77 & $59 \%$
\end{tabular}

2 Borð og stólar í U, nemendur snúa hver að öðrum eða að vegg $12 \quad 9 \%$

3 Hópuppröðun borða/klasar, nemendur snúa hver að öðrum (ekki endilega $29 \quad 23 \%$ samvinna)

4 Annað (t.d. verkstæði, ípróttir) $\quad 12 \quad 9 \%$

$130 \quad 100 \%$

Hugmyndir nemenda, eins og pær birtust í viðtölunum, voru bornar saman við aðstæður í skólastofunum eins og peim var lýst í vettvangsathugunum og birtust á ljósmyndunum.

\section{Niðurstöður}

Í pessum kafla er gerð grein fyrir helstu niðurstöðum. Fjallað er sérstaklega um pær aðstæður sem lentu oftast í tveimur efstu röðunum eða í tveimur peim neðstu í tíglinum, pað er voru taldar góðar eða ekki góðar aðstæður fyrir nám. Dá er farið yfir niðurstöður sem varða möguleika nemenda til að hafa áhrif á umhverfi sitt. Í töflu 3 má sjá yfirlit yfir pað hvernig nemendur röðuðu myndum af aðstæðum í tígulformið og hversu oft hver mynd var valin. Mynd a, til dæmis, sem sýndi hefðbundið skipulag par sem borðum var raðað pvert yfir stofu og allir sneru andliti í sömu átt, var af premur hópum metin sem góðar ađstæður til náms og pví skipað í röð 1 eða í röð 2. Níu hópar settu hana pó í röð 4 eða röð 5, sem sýnir að peir hópar mátu pær aðstæður ekki góðar til náms. Par sem myndirnar voru fleiri en reitirnir í tíglinum ákvað hver hópur hvaða myndir skyldu notaðar og hverjar ekki. Til dæmis má sjá að einungis prír hópar notuðu mynd l, sem sýndi framúrstefnulega tæknistofu, á meðan allir hóparnir 17 notuðu mynd a í sinn tígul. Svo virtist sem hóparnir notuðu síður myndir sem sýndu aðstæður sem peir höfðu ekki reynslu af.

Tafla 3. Yfirlit yfir val hópanna (17 hópviðtöl).

\begin{tabular}{llcccccc}
\hline Mynd: & Námsumhverfi: & Röð 1 & Röð 2 & Röð 3 & Röð 4 & Röð 5 & Alls \\
Mynd a & Hefðbundið skipulag & 2 & 1 & 5 & 6 & 3 & 17 \\
Mynd b & Setið í hópum & 4 & 1 & 7 & 4 & 0 & 16 \\
Mynd c & Einkaborð & 3 & 2 & 7 & 0 & 1 & 13 \\
Mynd d & Hópvinna & 1 & 2 & 6 & 5 & 2 & 16 \\
Mynd e & Tölvuvinna, hvar sem er í húsnæðinu & 1 & 6 & 4 & 2 & 1 & 14 \\
Mynd f & Tölvustofa & 0 & 0 & 2 & 7 & 4 & 13 \\
Mynd g & Vettvangsferð & 1 & 6 & 3 & 5 & 0 & 15 \\
Mynd h & Fyrirlestrasalur & 0 & 1 & 4 & 4 & 3 & 12 \\
Mynd i & Einn við lestur & 3 & 5 & 4 & 1 & 0 & 13 \\
Mynd j & List- og verkgreinar & 3 & 0 & 4 & 0 & 3 & 10 \\
Mynd k & Bókasafn & 2 & 9 & 3 & 0 & 1 & 15 \\
Mynd 1 & Tæknistofa & 0 & 1 & 2 & 0 & 0 & 3 \\
\hline
\end{tabular}

^fjöldi hópa sem notar viðkomandi mynd

Af töflu 3 má sjá að talsverð dreifing var á milli hópanna hvað varðaði álit peirra á peim aðstæðum sem myndirnar sýndu.

Á mynd 3 er samantekt um pað hve oft hver mynd fær stað í tveimur efstu röðum tígulsins (raðir 1 og 2), og dæmist par með sem góðar aðstæður til náms, í miðröðinni (röð 3) og í tveimur neðstu röðunum (raðir 5 og 6) sem ekki svo góðar aðstæður til náms. 


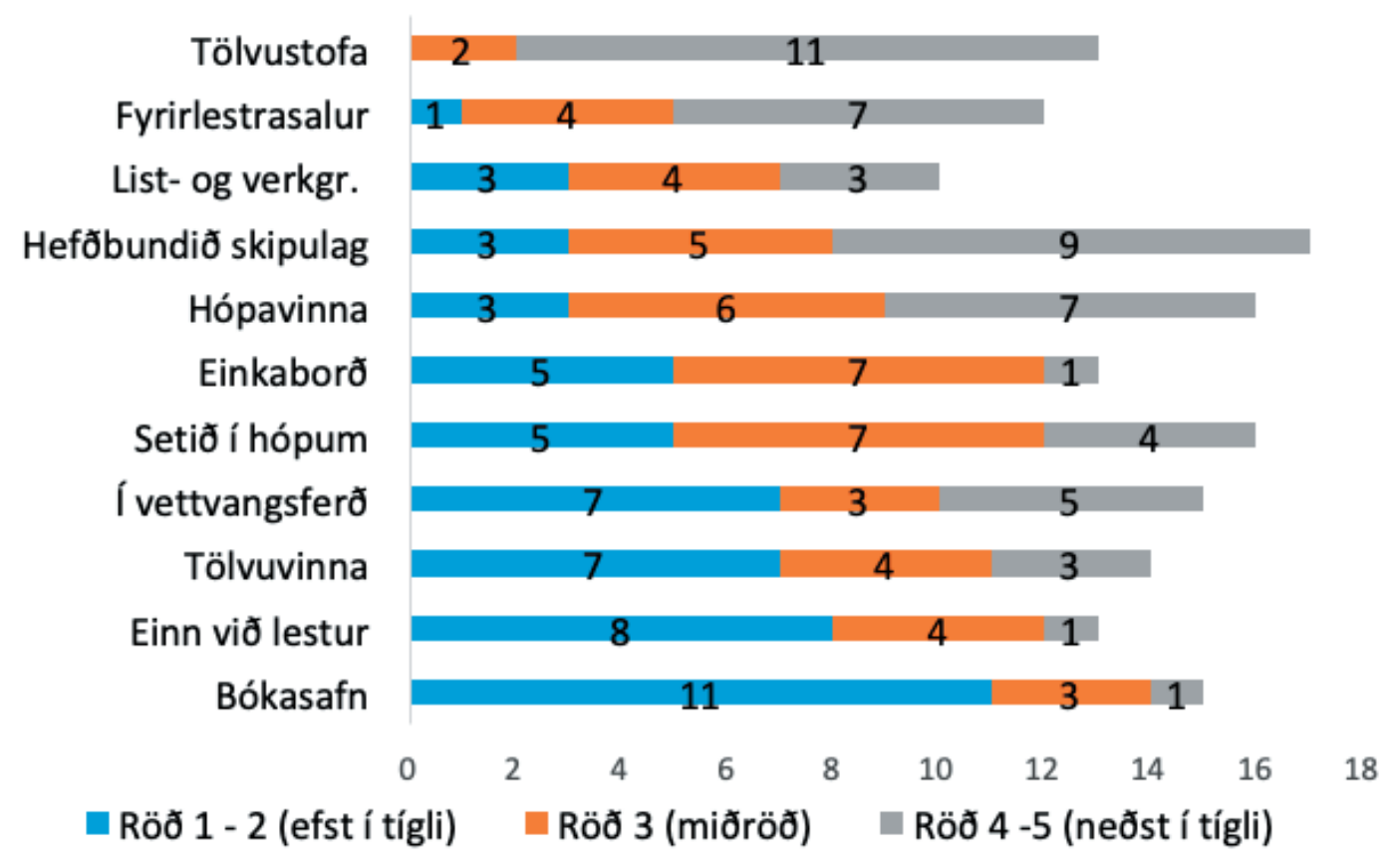

Mynd 3. Yfirlit yfir pað hversu oft hver mynd fékk stað í efstu röðum tígulsins, í miðju og í neðstu röðum.

Hér er einungis fjallað um pær ellefu myndir sem oftast voru notaðar og tekið saman hversu margir hópar settu pær efst, í miðið eða neðst í tígulinn. Rétt er pó að taka fram að röðin segir ekki allt um vinsældir eða óvinsældir viðkomandi aðstæðna, ummæli nemenda gáfu ekki síður vísbendingar og verður gerð grein fyrir peim. Hér á eftir er greint frá nokkrum dæmum um aðstæður sem taldar voru góðar til náms og aðstæður sem póttu síður góðar.

Dami um aðstæeður sem taldar voru góðar til náms

Myndin af bókasafni (mynd 4) fékk oftast stað í tveimur efstu röðum tígulsins, eða hjá ellefu hópum af peim fimmtán sem notuðu myndina, en einungis hjá einum hópi í neðstu röđunum. Pátttakendur nefndu mun oftar jákvæða pætti i tengslum við bókasafn en neikvæða. Helst nefndu peir að par ríkti ró og friður og væri pægilegt og „kósý“, eða eins og nemendur í einum hópnum orðuðu pað:

Bara pægilegt ... friður og ró, enginn hávaði ... Gott aðgengi að heimildum ... Svo eru tölvur parna við hliðina á bókasafninu líka, ef maður parf ... pannig að pað er eiginlega allt parna inni sem maður parf.

Í einum skólanum ræddu pátttakendur kosti bókasafna, svo sem að par væri hægt að sitja í nálægð við aðra nemendur, pó að peir væru ekki endilega að læra saman. Í öðrum skóla nefndu pátttakendur að bókasafnið væri teppalagt og svo skipt upp , pannig að maður parf ekki, pú veist að horfa á alla í kringum sig“".

Verst fannst peim pegar nemendur virtu ekki reglur og notuðu bókasafnið til að hittast og tala saman fremur en til að læra, eins og eftirfarandi ummæli gefa til kynna:

Par voru svona litlir hópar sem voru að tala og pú veist, peir voru ekkert inni á bókasafni til að læra, peir vo ru bara parna ... ég veit um vinahóp sem sat alltaf bara inni á bókasafni.

Einnig fannst nokkrum hópum ókostur að geta ekki notað bókasafn skólans um helgar, til dæmis til að læra eða undirbúa sig fyrir próf, par sem pá er pað lokað. 


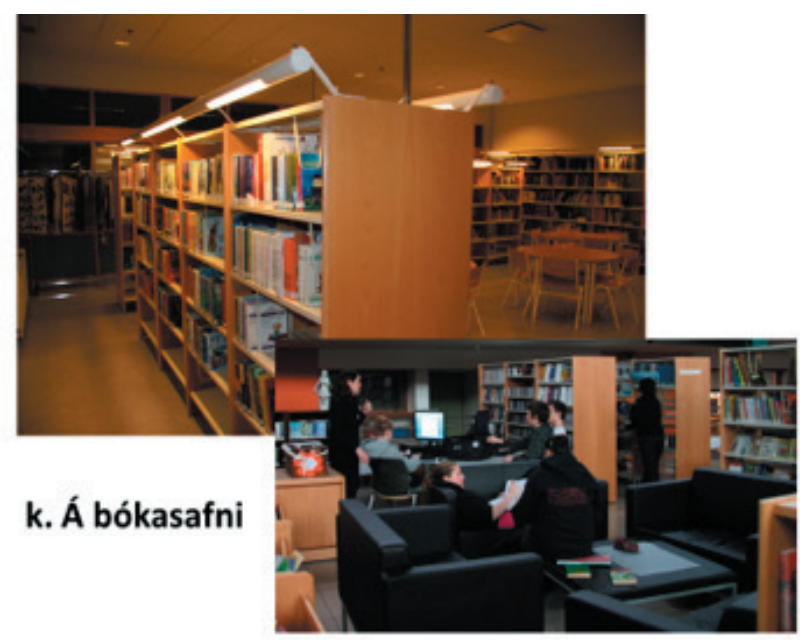

Mynd 4. Á bókasafni (mynd k).

Bókasöfn eiga pað oftast sameiginlegt að par er gott næði til að lesa eða læra og par er hægt að sitja í hópum eða vera einn. Dar eru pví ekki ólíkar aðstæður peim sem sýndar voru á mynd i (að sitja ein/n við lestur í friði og ró) og mynd e (að vinna ein/n í tölvu hvar sem er). Dví kemur ekki á óvart að myndirnar raðast nokkuð svipað í tíglinum (sjá töflu 2). Pátttakendur töldu pessar aðstæður henta sérstaklega vel ef peir vildu einbeita sér og voru pví fremur jákvæðir gagnvart pess konar námsumhverfi. Ókosti pess að sitja einn í ró og næði og lesa töldu peir vera pá helsta að fáir læri með pví einu að lesa, ,,pað hentar voðalega fáum, finnst mér“ sagði nemandi í einum hópnum. Annar sagðist sofna ef hann notaði pessa aðferð við lærdóminn og enn annar sagði að svona umhverfi myndi helst henta peim sem hefðu mikinn áhuga á lestri.

Mynd b, sem lýsti aðstæðum par sem hægt er að sitja saman í hóp, án pess pó endilega að vera í hópvinnu, fékk jákvæða umsögn frá flestum hópunum (mynd 5). Dá er borðum raðað pannig að 4-6 nemendur geta setið saman við eitt stórt borð sem myndar klasa í skólastofunni eða nokkur stór borð eru í stofunni sem 6-8 nemendur geta setið við. Fimm hópar af peim sextán sem notuðu myndina röðuðu pessum aðstæðum í tvær efstu raðirnar, par af fjórir í efstu röð (tafla 3). Í umræðum kom fram að helsti kostur pessa fyrirkomulags væri frelsið til að ákveða sjálf/sjálfur hvort unnið væri sjálfstætt eða í samvinnu við aðra. Í einum skólanum, par sem báðir viðtalshóparnir settu pessa mynd í fyrstu röð, kom fram að gott væri að tilheyra hópi, pað væri hvatning til að halda sig við námsefnið og líklegra að lærdómur færi fram ef nemendur töluðu saman um námið.

Nemendur geta stutt hver annan á ýmsum sviðum pví styrkleikar peirra sem sitja saman við borðið eru mismunandi, eða eins og nemandi orðaði pað:

Mér finnst pað geðveikt pæegilegt, eins og maður er að vinna verkefni, ef við skiljum ekki eitthvað pá getum við pikkað í fólkið sem situr við hliðina á manni.

Gott var einnig ef sessunautur var ekki endilega á sama sviði og nemandinn sjálfur, pannig væri breið pekking við borðið sem nýttist öllum hópnum: „Fólkið í hópnum er yfirleitt af mismunandi sviðum. Раð er gott ... pannig að maður getur spurt.“

Sem helsta ókost við petta fyrirkomulag nefndu pátttakendur að nemendur kæmu oft ekki miklu í verk par sem peir færu að spjalla of mikið um eitthvað annað en námið eða að aðrir við borðið trufluðu með pví að spjalla of mikið.

Dæmi um aðstæður sem nemendur pekktu lítið en fengu samt jákvæða umsögn var mynd c sem sýndi pað að hafa aðgang að einkaborði í skólanum sem hægt væri að ganga að hvenær sem væri pegar pað hentaði viðfangsefnum og vinnubrögðum (mynd 6). Pessa mynd völdu prettán hópar 


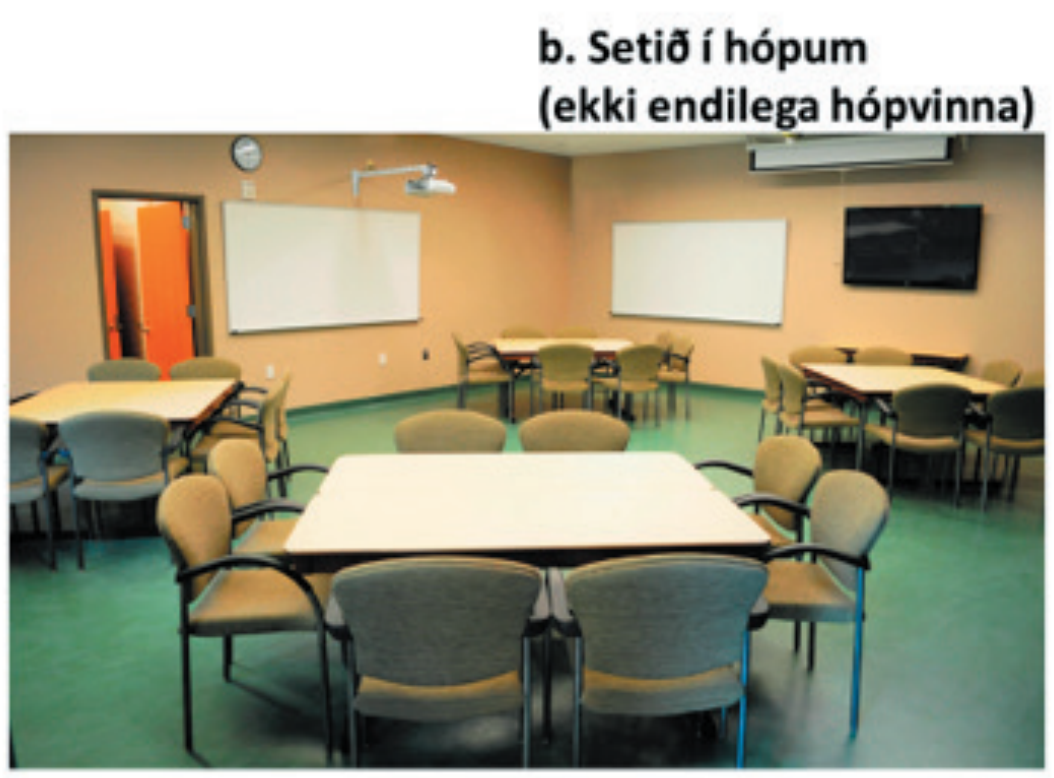

Mynd 5. Setið í hópum (mynd b).

og fimm peirra settu hana í efstu raðirnar en sjö hópar settu hana í miðröð, peim fannst petta athyglisverð hugmynd pótt peir hefðu ekki reynslu af slíkum aðstæðum.

„Erum við ekki sammála um pað að petta væri snilld, eða, einkaborð í skólanum?“ spurði einn nemandinn félaga sína í hópnum. Peir tóku undir pað. Annar nemandi sagði: „Sko, pegar við erum að hugsa um nám, pá er petta örugglega mjög gott, sko.“

Dátttakendur í hópunum höfðu almennt ekki heyrt um svona fyrirkomulag en sáu fyrir sér að раð væri pægilegt að vera par sem enginn truflaði, jafnvel að peir gætu lært meira og betur í slíku námsumhverfi. Deir bentu pó á hversu plássfrekt pað væri að hver nemandi hefði sitt einkaskrifborð auk pess sem peir pyrftu að hafa mikinn sjálfsaga til að pað myndi nýtast vel til аð læra.

Einungis tíu hópar notuðu mynd sem sem sýnir aðstæður til verk- og listgreinakennslu, sem er eðlilegt miðað við pað hve fáir viðmælendur voru í verklegu námi. Einn pátttakandi sem stundaði verklegt nám hafði petta að segja:

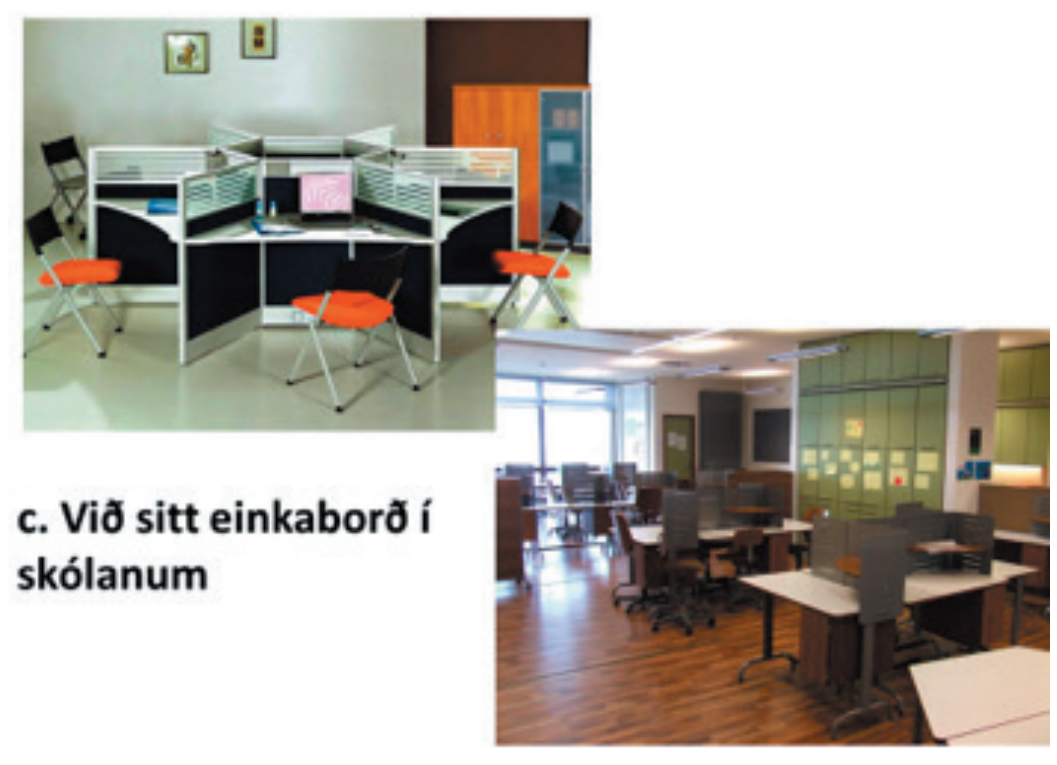

Mynd 6. Setið við sitt einkaborð í skólanum (mynd c). 
Detta er held ég bara með krakka, peir læra miklu meira af pví sem pau sjá og gera sjálf, að herma eftir foreldrum sínum.... Dú réttir ekki bara krakka, hérna, petta eru reglurnar í lífinu, lærðu petta. Maður lærir af pví sem maður gerir og síðan bara lærir maður af mistökum. Ef maður er að vinna með eitthvað í höndunum, maður sér hvernig petta er gert og ... maður sér hvernig petta er vitlaust gert, í staðinn fyrir að vera með blað og blýant og skrifa niður einhver svör sem maður notar síðan aldrei aftur. Svona læra að vinna bara.

Nemendur sem stunduðu nám á bóknámsbrautum sáu ekki kostina við verk- og listgreinar sem pessi nemandi sá, enda höfðu peir valið sig frá peim.

\section{Dæmi um aðstæður sem ekki voru taldar vera góðar til náms}

Myndum sem sýndu aðstæður sem nemendur töldu ekki góðar til náms var raðað í tvær neðstu raðirnar (röð 4 og röð 5). Hér verður fjallað um prjú dæmi, hefðbundna skólastofu, tölvustofu og hópvinnu.

Hefðbundin skólastofa er líklega pað sem kemur í hug flestra pegar umhverfi í skólastofu ber á góma. Pá er borðum raðað, premur til sex saman, í beina röð pannig að allir nemendur snúa í sömu átt og horfa á eða hlusta á kennarann (mynd 7).

Allir hóparnir notuðu pessa mynd í tígulinn sinn en oftast lenti hún frekar neðarlega. pó hún hafi líka verið valin tvisvar sinnum í efstu röðina með peim rökum að nemendur væru vanir pví að læra í pessu umhverfi, pekktu pað best. „Mér finnst petta alls ekki slæmt,“ sagði einn pátttakandinn og annar sagði: „maður bara venst, ólst upp við petta í grunnskólanum“. Deir hópar sem hins vegar kusu að hafa pessa mynd neðarlega sögðu að hefðbundin skólastofa væri fremur tilbreytingarlaust umhverfi, eða eins og einn viðmælandi orðaði pað: „,kannski finnst manni pað leiðinlegast par sem pað er búið að vera pannig síðan í 1. bekk“.

Virðist pví sem einhæft umhverfi sé meðal annars ástæða pess að hefðbundin skólastofa lenti í neðstu röðunum og undir pað taka pátttakendur í einum hópnum eins og eftirfarandi samræða ber með sér:

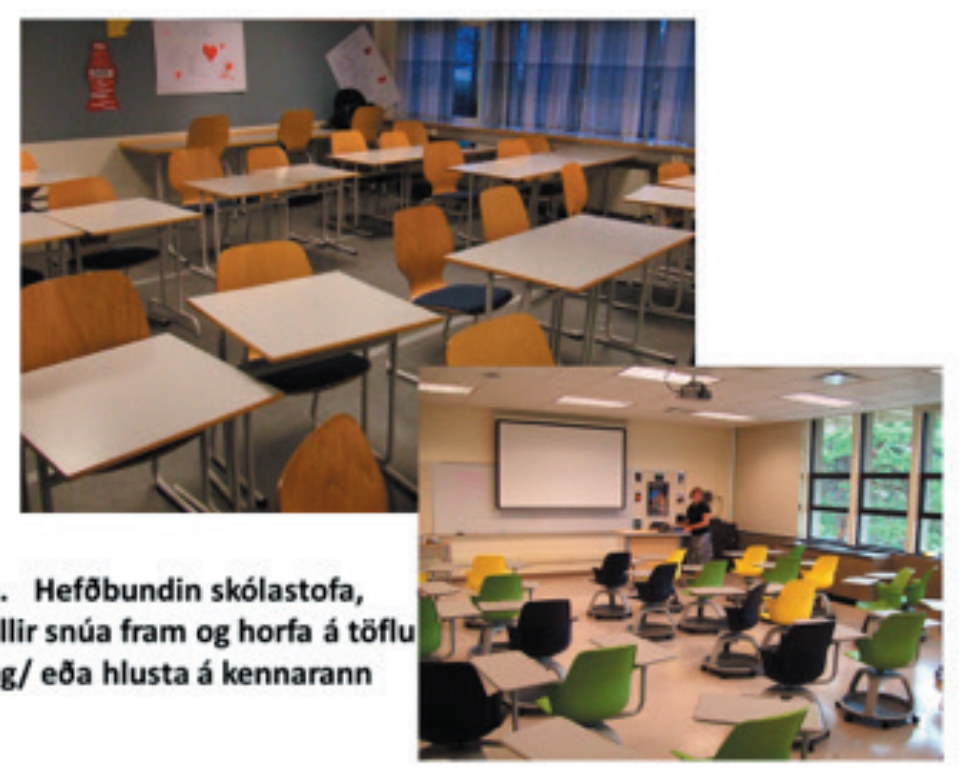

Mynd 7. Hefðbundin skólastofa (mynd a). 
N1: Dað er petta sem við erum að mótmæla, sitja alltaf og hlusta og skrifa.

N2: Баð er líka bara pað að pað sé einhæft, að pað sé alltaf svona.

N3: Allt í lagi að hafa einstaka tíma sem eru svona ef pað væru ekki allir.

Tölvustofan er sú stofa sem flestir voru sammála um að væri ekki góður staður til náms, enginn hópur raðaði peirri mynd í efstu raðirnar en níu hópar settu hana neðst. Dótt sérstakar tölvustofur væru ekki í öllum peim framhaldsskólum sem voru heimsóttir pekktu nemendur vel slíkt umhverfi. Deim pótti umhverfið truflandi og pröngt, ,eins og maður sé að kafna,“ eins og einn nemandinn orðaði pað, og annar sagði: „,pað eru endalausar tölvutruflanir og truflanir frá öðru fólki og truflanir frá öllu“. Nemendur sögðu oft ópægilega heitt í pessum stofum, auk pess sem pað væri hvergi pláss fyrir dótið peirra.

Ein myndin (d) sýndi hópvinnu sem gat farið fram hvar sem var í skólanum (mynd 8). Detta er aðferð sem flestir nemendur pekkja vel en var engu að síður raðað í neðstu raðirnar af sjö hópum en einungis prír hópar settu pær í efstu raðirnar. Nemendur í einum hópnum sögðu að besta leiðin til að læra eitthvað væri að tala um pað við aðra. Engu að síður fengu pessar aðstæður fremur neikvæðar athugasemdir (mynd 3).

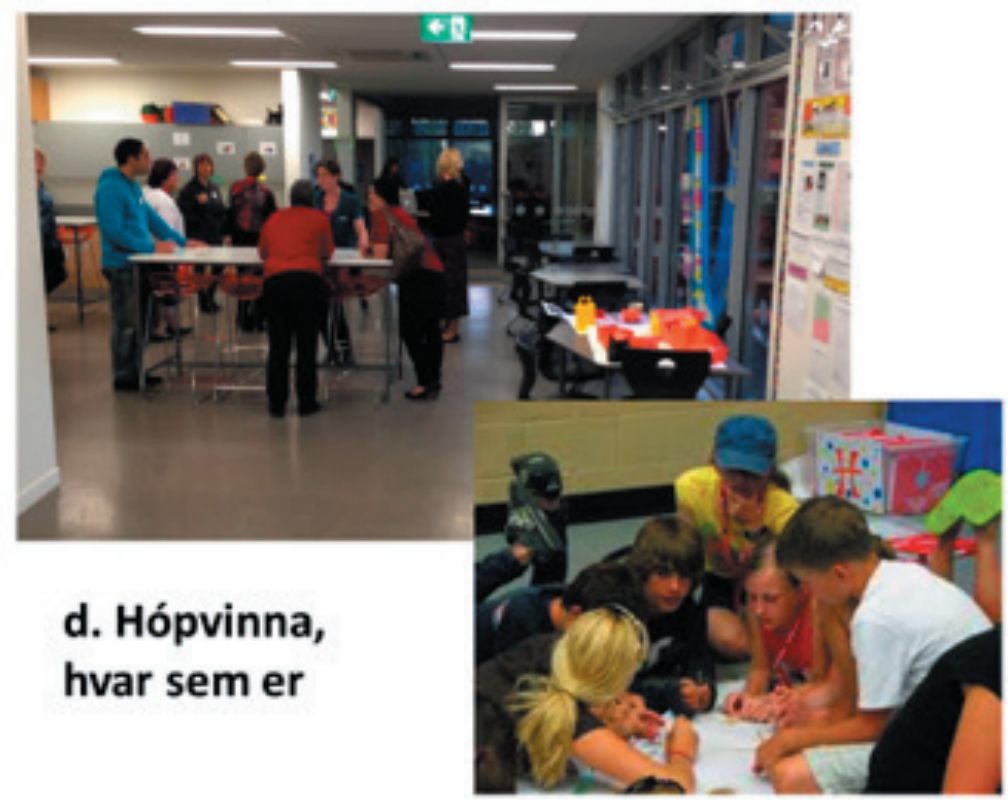

Mynd 8. Hópvinna, hvar sem er (mynd d).

Pátttakendur sögðu vissulega gott að læra með öðrum en of algengt væri að hluti hópsins væri óvirkur pannig að vinnan lenti á einum eða fáum, sérstaklega ef hópurinn væri of fjölmennur. Nemandi í einum skólanum lýsti pessu svona:

Dað er yfirleitt einn sem endar á pví að gera hópverkefni og hinir fá bara svona miða ... farðu yfir petta og, pú veist, pessi parna eini sem vill fá hátt í verkefninu prentar petta allt út og klippir og gerir petta fint. Lætur síðan alla hina hafa petta.

Nemandi i öðrum skóla tók í sama streng en taldi pó stærð hópsins skipta máli:

Allt í lagi ef pað eru svona prír í hóp, ef pað er meira en pað pá allavega finnst mér að, pá eru alltaf einhverjir sem gera ekki neitt og maður getur alveg eins bara, pú veist.

Einn nemandi í skóla $\mathrm{H}$, sem ekki var jákvæður gagnvart hópvinnu, taldi jafnvel að peir nemendur sem vildu hafa hópvinnu væru einmitt peir sem kæmu sér undan vinnu: „,peim sem finnst pægilegra að vera í hópvinnu finnst pað pægilegra pví pá eru pau ekki að gera jafn mikið“. 


\section{Áhrif nemenda á aðstæður til náms}

Í viðtölunum voru nemendur spurðir hvort peir hefðu möguleika á að hafa áhrif á námsumhverfi eða pær aðstæður sem peir lærðu í. Auk pess var greint í vettvangslýsingum hverrar kennslustundar hvort nemendum væri boðið upp á slíkt val.

Í viðtölum litu nemendur gjarna undrandi hver á annan pegar peir voru spurðir hvort peir fengju tækifæri til að hafa áhrif á aðstæður sínar til náms. Greinilegt var að peir höfðu ekki velt pessu fyrir sér, höfðu ekki ,pælt í pvi““ eins og einn nemandi sagði. Peir voru pó almennt á pví að peim stæði pað ekki til boða en myndu hins vegar vilja pað ef peir gætu.

Dessi viðbrögð nemenda voru staðfestí vettvangsathugunum, par sem fá dæmi sáust um að nemendur gætu haft áhrif á aðstæður sínar. Eins og lesa má af töflu 2 fóru tæplega $60 \%$ kennslustunda fram í „hefðbundnum“ kennslustofum par sem nemendur sátu við einstaklingsborð, gjarnan í röðum pvert yfir stofu, og sneru allir andliti í sömu átt, að kennara sem var fremst í stofunni. Aðstæður í pessum stofum virtust vera í nokkuð föstum skorðum og sveigjanleiki ekki mikill. Í slíkum stofum sáust fá tilvik par sem kennarar buðu nemendum upp á að breyta um umhverfi og nemendur óskuðu heldur ekki eftir pví. Hér á eftir fara dæmi um lýsingar rannsakenda á premur kennslustundum í hefðbundnu kennslurými:

Kennslustundin einkenndist af beinni einhliða miðlun. Kennari notaði glærur og gekk fram og til baka framarlega í stofunni vegna plássleysis. Hann var líflegur, sagði skemmtilega frá og notaði líkamann mikið sem frásagnartæki ásamt pví að benda á töfluna. Nemendur spurðu annað slagið og pá einkum fjórir áhugasamir nemendur. Hinir voru hljóðir. Kennari spurði salinn nokkrum sinnum. Nokkrir gripu í símann sinn pegar líða fór á kennslustundina og einn nemandi fór í tölvuna í tölvuleik.

Í öðrum tíma, sem var umræðutími par sem kennari lagði sig fram um að virkja nemendur í umræðum, skráði athugandi petta hjá sér:

Uppröðun í stofunni var óheppileg fyrir vinnu af pessu tagi par sem kennari átti erfitt með að halda tengslum við alla nemendur og nokkuð erfitt var að skapa umræðu.

Af vettvangsnótum má lesa að kennslan var kennarastýrð og alla jafna ekki gert ráð fyrir að nemendur hefðu áhrif, hvorki á aðstæður, inntak náms né aðferðir. Hugsanlega gætu nemendur pó haft áhrif ef peir óskuðu eftir pví, en ljóst má vera að annað fyrirkomulag á uppröðun húsgagna hefði hentað betur í pessu tilfelli.

Dótt lýsingarnar hér að framan eigi við skólastofur með hefðbundnu skipulagi borða er ekki hægt að álykta að áhrif eða áhrifaleysi nemenda tengist endilega skipulagi stofunnar. Námsgreinar og viðfangsefni hverju sinni hljóta óhjákvæmilega að hafa áhrif.

Í kennslustund par sem nemendum var boðið að hafa áhrif á aðstæður gátu peir farið út úr kennslustofunni og unnið í annarri stofu, frammi á gangi eða par sem peir vildu. Virtust nemendur pekkja fyrirkomulagið og nýttu sér pað margir eins og eftirfarandi lýsing ber með sér:

Kennslustundin einkenndist af frjálsri verkefnavinnu nemenda. Mjög afslappað andrúmsloft var í stofunni, nemendur fóru út og komu aftur, að pví er virtist að vild. Kennari gekk á milli nemenda og ræddi við pá á óformlegan hátt um hugmyndir peirra í verkefnavinnunni. Greinilegt var að kennari vildi að nemendur próuðu hugmyndir sínar sjálfir og fyndu leiðir til að útfæra pær.

Annað dæmi er úr áfanga úr öðrum skóla par sem skólastofur voru alla jafna með hefðbundnu skipulagi og átti pað einnig við um skólastofuna par sem pessi kennslustund byrjaði: 
Nemendur vinna í hópum eða einstaklingslega að pví að skapa eitthvað úr endurnýtanlegu efni. Nemendur dreifast í allar áttir rétt eftir að tíminn byrjar og einungis 2-3 nemendur eru eftir 1 stofunni. Pau fara flest 1 aðra stofu til að vinna verkefnin sín. ... Nemendur ráða nánast alveg hvað pau gera og hvernig en skila skýrslu og mynd fyrir og eftir um hverja hugmynd.

Dessar kennslustundir virtust einkennast af pví að nemendur væru hvattir til að ákveða sjálfir hvar og hvernig peir ynnu verkefni sín. Hlutverk kennarans virtist fremur vera að leiðbeina nemendum en að stýra peim og skilaboðin til peirra voru skýr, nemendur áttu sjálfir að ákveða. Darna skipti máli að fjölbreytt rými væri til staðar í skólanum fyrir ólík vinnubrögð par sem nemendur gætu valið sér aðstæður sem hentuðu viðfangsefninu hverju sinni.

\section{Samantekt og umræða}

Dessari rannsókn er ætlað að varpa ljósi á hugmyndir nemenda í íslenskum framhaldsskólum um kjöraðstæður til náms samanborið við pær aðstæður sem eru til staðar, og möguleika peirra til að hafa áhrif par á. Rannsóknarspurningarnar sem lagt var upp með voru:

c) Hverjar eru hugmyndir nemenda um gott námsumhverfi og hvernig samræmast pær raunverulegum aðstæðum í framhaldsskólum?

d) Telja nemendur sig geta haft áhrif á námsumhverfi eða pær aðstæður sem peir læra við?

Í viðtölum voru nemendur spurðir um hugmyndir sínar um góðar aðstæður til náms og hvort peir hefðu möguleika á að hafa áhrif á aðstæður sínar til náms. Leitað var eftir upplýsingum um áhrif nemenda á umhverfi sitt í vettvangsathugunum, auk pess sem skólastofur voru flokkað eftir uppröðun og skipulagi húsgagna. Niðurstöður eru ræddar í tengslum við kenningar um nemendamiðað nám, sem virðist stuðla að skuldbindingu nemenda gagnvart skólaverkefnum (sjá t.d. Blackmore o.fl., 2011; Fredricks o.fl., 2004) sem aftur gæeti leitt til minna brotthvarfs (Kristjana Stella Blöndal og Sigrún Ađalbjarnardóttir, 2012) (sjá mynd 1).

\section{Hugmyndir nemenda og aðstæður í framhaldsskólum}

Niðurstöður gefa til kynna að nemendur sem tóku pátt í pessari rannsókn kjósi helst umhverfi sem býður upp á fjölbreytni og sveigjanleika. Рað er í góðu samræmi við samantekt Blackmore o.fl. (2011) um rannsóknir á pessu sviði. Til að mynda vilja peir gjarna geta ákveðið hvenær peir vinna með öðrum og hvenær ekki og geta verið í friði og ró pegar pað hentar. Að sama skapi líkaði peim síður umhverfi sem er í mjög föstum skorðum, ýtir undir einhæfar námsaðferðir og er pröngt og afmarkað. Góður samhljómur var um petta með áströlsku nemendunum sem tóku pátt í rannsókn Mulachy o.fl. (2015), en peir kunnu vel að meta svigrúm sem peir höfðu til að hafa áhrif á aðstæður sínar til náms.

Tölvustofur reyndust vera óvinsælustu stofur skólans og bjóða upp á afar lítið svigrúm eða sveigjanleika, nema auðvitað pann sem fylgir hinu rafræna umhverfi. En pað nefndu nemendur ekki í pessu samhengi. Detta á einnig við um hefðbundnar kennslustofur par sem borð eru í röðum og allir snúa andliti í sömu átt. Pátttakendur viðurkenndu að vísu að slíkar aðstæður gætu stundum hentað mjög vel en pær væru leiðigjarnar til lengdar. Einn pátttakandi tengdi pær við einhæfar kennsluaðferðir par sem nemendur ættu bara að hlusta og skrifa, sbr. ábendingu Veloso og félaga (2015) um umhverfi fyrir kennsluhætti sem byggja á úreltum hugmyndum um nám. Pannig umhverfi reyndist einmitt vera hvað algengast í peim skólum sem voru hér til skoðunar eða í tæplega 60\% peirra 130 kennslustunda sem heimsóttar voru. Detta parf ekki að koma á óvart og hefur komið fram í öðrum rannsóknum, bæði á grunn- og framhaldsskólum hér á landi (Anna Kristín Sigurðardóttir, 2014; Gerður G. Óskarsdóttir, 2012). 


\section{Áhrif nemenda á aðstæður til náms}

Dátttakendur í viðtölunum upplifðu almennt að áhrif peirra væru lítil á umhverfi og aðstæður, peir virtust jafnframt vera lítt meðvitaðir um umhverfi sitt og höfðu greinilega ekki gert ráð fyrir pví að fá að hafa áhrif á aðstæður sínar til náms. Đað styðja vettvangsathuganirnar par sem möguleikar nemenda til að hafa áhrif voru lítt eða ekki sýnilegir og skipulag á umhverfi bauð alla jafna ekki upp á mikinn sveigjanleika.

Detta valda- og áhrifaleysi nemenda rímar vel við hugmyndir Markus (1993) sem hann setti fram fyrir um aldarfjórðungi. Hann sagði að hefðbundið skipulag eins og pað birtist í skólastofum og fyrirlestrasölum, með kennarann í lykilhlutverki, væri beinlínis hannað til að undirstrika völd kennarans sem pess sem hefur pekkinguna og valdaleysi peirra sem taka við, nemendanna. Рað er pó athyglisvert að um leið og nemendur kjósa aukið svigrúm og meiri áhrif kalla peir á umhverfi sem heldur peim við efnið. Umhverfi par sem peir verða síður fyrir truflunum eða leiðast út í óparfa samræður við skólafélagana.

Dað kom nokkuð á óvart hve nemendur höfðu almennt lítið velt fyrir sér aðstæðum til náms og pví hvort peir gætu haft áhrif par á. Ekki er ólíklegt að niðurstöður Imms og fleiri (2016) um að kennarar séu almennt illa læsir á umhverfi sitt (e. space litaracy) eigi líka við um nemendur. En umhverfislæsi vísar meðal annars til pess hve viðkomandi er glöggur að greina möguleika á að móta umhverfið í págu eigin starfshátta samkvæmt Moore-Russo og félögum (2013). Pau benda reyndar á mikilvægi pess að pjálfa umhverfislæsi á öllum skólastigum, meðal stjórnenda, kennara og nemenda.

Ljóst er að óljósar skoðanir viðmælenda á pví hvort, og pá hvernig, umhverfið hentar peim til náms gerir rannsókn eins og pessa erfiða. Í slíkum tilvikum hentar vel að nota myndir til að kveikja umræður, eins og gert var hér (sbr. Clark, 2012). Dó ber að hafa í huga að myndir geta einnig verið takmarkandi par sem umræðan getur snúist of mikið um pað sem myndirnar sýna, eins og Norlander (2014) bendir á, og lítið svigrún verður pá fyrir nýjar hugmyndir. En pátttakendur í hópunum voru fljótir að taka við sér pegar myndirnar voru dregnar fram og líflegar umræður kviknuðu.

\section{Námsumhverfi og nemendamiðað nám}

Lítið er vitað um tengsl námsumhverfis við nám og kennslu og par með talið hvernig umhverfið getur stutt nemendamiðað nám. Líkan kanadíska fræðimannsins Gislason (2010) lýsir pví vel að áhrifin séu óbein og gerist í flóknu samspili margra pátta. Áströlsku fræðimennirnir Mulcahy og fleiri (2015) taka undir petta, en pau fundu engin bein tengsl á milli kennsluhátta og umhverfis. Framhaldsskólanemendur sem pau ræddu við voru pó á einu máli um að pað skipti pá máli að geta haft áhrif á aðstæður sínar, og töluðu par af reynslu.

Fá einkenni nemendamiðaðs náms eins og Land, Hannafin og Oliver (2012) lýsa pví komu fram 1 gögnunum. Nemendur höfðu lítil áhrif á eigið lærdómsferli, hvort sem um var að ræða inntak, áherslur, aðstæður eða aðferðir. Par sem nemendur sitja í hefðbundnum röðum í kennslustofu virðast möguleikar á sveigjanlegum námsleiðum fremur litlir pví námsumhverfið er í nokkuð föstum skorðum. Dar sem nemendur sitja í klösum (nokkrir saman við borð) aukast möguleikar peirra til að vinna á mismunandi hátt og sveigjanleiki er meiri. Í óhefðbundnu kennslurými hafa nemendur enn meiri möguleika á mismunandi námsleiðum í sveigjanlegu námsumhverfi par sem peir hafa valmöguleika, og sama má segja um svokölluð verkstæði sem nokkuð var um.

Eins og ljóst má vera af umfjölluninni hér að framan ríkir almennt áhrifaleysi nemenda; pað endurspeglaðist vel í vettvangsathugununum, með örfáum undantekningum. En ef marka má niðurstöður fjölmargra rannsókna sem vitnað hefur verið til í pessari grein gæti aukin áhersla á nemendamiðað nám stuðlað að aukinni skuldbindingu nemenda og jafnvel einnig peirra nemenda 
sem ekki finna sig í skólanum (sjá til dæmis Fredricks o.fl., 2004 og Smit o.fl., 2014).

Prain og fleiri (2015) bentu á að nemendamiðað nám væri algengara í opnum skólum en peim hefðbundnari, sem aftur gefur til kynna að umhverfið geti haft áhrif á nám og kennslu. Alterator og Deed (2013) taka undir petta. Kennarar sem tóku pátt í rannsókn peirra störfuðu í opnu og sveigjanlegu rými, peir unnu mikið saman og dreifðu ábyrgð til að geta komið betur til móts við nemendur. Ekki er mikið vitað um viðhorf nemenda, en peir sem tóku pátt í rannsókn Mulcahy o.fl. (2015) tjádu ánægju með pann sveigjanleika sem peir höfðu.

\section{Að lokum}

Dótt pessi rannsókn takmarkist við aðstæður til náms í skólahúsnæðinu, pá er mikilvægt að hafa í huga að námsumhverfi nemenda er víðar, til dæmis á netinu, utan skólans á heimilinu og víðar. Skólaumhverfið hefur pó pá sérstöðu að pað er sérstaklega hannað og útbúið til að bjóða upp á kjöraðstæður til náms og talsverðu er til kostað af fé til að svo megi verða. Í ljósi pess er undarlegt hve litla athygli fræðimanna tengsl umhverfis og náms hafa hlotið, bæði hér á landi og víðar. Dessi rannsókn er pví veruleg nýlunda.

Í inngangi var sett fram skýringarmynd til að sýna að nemendamiðað námsumhverfi gæeti haft óbein jákvæð áhrif á námsárangur og velllíðan nemenda (mynd 1). Ekki var ætlunin að sanna tengsl milli pessara pátta heldur einungis að kanna hvort og pá hvernig námsumhverfi framhaldsskóla á Íslandi styður nemendamiðað skólastarf, sem pað reyndist ekki gera nema að litlu leyti. Sú hugmynd um orsakasamhengi sem lýst er á mynd 1 kallar á frekari rannsóknir á tengslum umhverfis við kennsluhætti, námsárangur og almenna vellíðan nemenda. Vonandi verður pessi rannsókn hvatning til slíkra rannsókna, en ekki síður til aukinnar meðvitundar um mikilvægi hins manngerða námsumhverfis fyrir nám og kennslu. Ljóst er að breyting er að verða á hönnun skólabygginga grunn- og framhaldsskóla hér á landi, sem er próun sem hófst í kringum síðustu aldamót. Mikilvægt er að fylgjast með áhrifum peirrar próunar á nám og kennslu, og ekki síst að hlusta á hvað nemendur hafa að segja um kjöraðstæður til náms.

\section{A student centred learning environment. Students' ideas about good spaces for learning}

The aim of the study is to shed light on students' ideas about good learning environments (spaces for learning) and how their ideas fit in with actual arrangements in school. Student-centred learning is in focus, as it reflects the possibilities for students to influence their own learning environment.

By a space for learning, we mean the physical learning environment such as places in the school building that are available for different learning activities, the arrangement of furniture in the classrooms and technology. The study is limited to the space inside the school building or activities on behalf of the school, such as fieldtrips. The results are reviewed from the perspective of a student-centred learning environment and student engagement, which has gained increasing attention in the research literature. It is assumed that a physical learning environment in coherence with students' ideas about good places for learning is student-centred and a supportive condition for student engagement in school; consequently, it might enhance students' well-being so that they are less likely to drop out.

A student-centred learning environment is based on constructivist approaches to learning, assuming that students' active participation in shaping their study environment is a fundamental condition for learning; thus, the learner must be active 
in building his or her own understanding. This calls for environments to provide multiple activities that enable individuals to address their own learning interests and needs and to study at multiple levels of complexity. The structure of daily school work must allow space for students to influence and participate in decision-making regarding their own learning environment. There is evidence to suggest that this kind of learning environment can support higher levels of perceived autonomy and student motivation. Different studies stress student autonomy and increased influence on their learning environment as one of the fundamental conditions for student engagement.

This research is part of a larger project on school practices in upper secondary schools in Iceland. Data were collected by classroom observations in 130 lessons and 17 group interviews with total of 56 students in nine upper secondary schools. To encourage discussion in the interviews, a diamond ranking method was used, involving nine pictures that participants were asked to arrange in a diamond shape. At the top of the diamond are pictures displaying an environment that students categorised as a good space/arrangement for learning, and at the bottom are the arrangements that students regarded as a space that was not good for learning, in the middle is an arrangement that was considered neither good nor bad.

The results show that classroom arrangements in the majority of the observed lessons could considered to be traditional, with students sitting at individual tables and everyone facing a blackboard in the front of the classroom. These were teachercentred lessons dominated by one-way instruction. This arrangement can hardly be seen as supportive of student-centred learning. Students' ideas about a good space for learning seemed to largely contradict the actual arrangements. They valued the learning environment when it gave them the flexibility or power to make decisions about their learning preferences. They liked to sit in groups where they could choose whether to work or consult with other students. They also liked the environment, for example libraries, where they could expect a quiet area and various working conditions. However, they did not value rigid environments for learning, one that is crowded, too hot or does not provide them with the flexibility to affect their situations. The students in this study were given few opportunities to make choices and had scant possibilities of influencing their learning. The students' ideas cohered well with international recommendations about innovative learning environments as well as results from other studies, thus making it worthwhile for education authorities at all levels to listen to them. Even though this study is limited in scope, hopefully the results can contribute to the discussion about ways to support students in constructing their own learning, knowledge and understanding. It is important to listen to students and provide them with opportunities to influence their own learning conditions in schools.

Key words: Physical learning environment, Diamond ranking method, Studentcentred learning, Student engagement, Upper secondary school

\section{Aftanmálsgrein}

[1] Megingagnasöfnun í rannsókninni Starfshættir í framhaldsskólum fór fram á tímabilinu október 2013 til nóvember 2014 í níu framhaldsskólum, auk pess sem rannsóknartækin voru forprófuð í tíunda skólanum. Gögnin eru vettvangslýsingar á 130 kennslustundum, yfir 60 afrituð viðtöl við nemendur (hópviðtöl), kennara og stjórnendur, ljósmyndir úr kennslustofum, kennsluáætlanir og önnur skrifleg gögn. Fimmtán manna hópur fræðafólks við Menntavísindaog Félagsvísindasvið Háskóla Íslands tók pátt í gagnasöfnuninni. Rannsóknin naut styrkja úr 
Rannsóknarsjóði Háskóla Íslands á árunum 2013-2015 og frá Norræna öndvegissetrinu Justice Through Education in the Nordic Countries, styrktu af NordForsk, 2013-2018. Við pökkum sérstaklega framhaldsskólunum sem veittu aðgang að starfinu í rannsóknarskyni.

Dessi grein er pýðing og endurskoðun á bókarkafla: Anna Kristín Sigurðardóttir. (2018). Studentcentred classroom environments in upper secondary school: Students' ideas about good spaces for learning vs. actual arrangements. Hér eru niðurstöður ræddar í samhengi við íslenskar aðstæður auk pess sem ítarlegar er gerð grein fyrir bakgrunni og niðurstöðum en í bókarkaflanum.

\section{Um höfundana}

Anna Kristín Sigurðardóttir (aks@hi.is) er prófessor við Menntavísindasvið Háskóla íslands og formaður námsbrautar um menntastjórnun og matsfræði. Hún er með B.Ed.-gráðu í grunnskólakennslu og M.Ed.-gráđu frá Kennaraháskóla Íslands. Doktorsgráđu lauk hún frá Háskólnum í Exeter 2006 á sviði menntastjórnunar. Rannsóknarsvið hennar tengjast menntastjórnun, skólapróun, lærdómssamfélag og námsumhverfi skóla og tengsl við kennsluhætti.

Sigrún Harpa Magnúsdóttir (sigrun.harpa.magnusdottir@reykjavik.is) er verkefnisstjóri á skóla- og frístundasviði Reykjavíkurborgar. Hún lauk B.Ed.-prófi i kennslufræðum frá Kennaraháskóla Íslands 2001, diplóma gráđu í verkefnisstjórnun frá University Lillebælt í Danmörku 2006 og M.Ed.-prófi í uppeldisog kennslufræðum með áherslu á matsfræði frá Háskóla Íslands 2015. Meginverkefni hennar á skóla- og frístundasviði eru að stýra ytra mati í grunnskólum og frístundastarfi Reykjavíkurborgar. Netfang: sigrun. harpa.magnusdottir@reykjavik.is

\section{About the authors}

Anna Kristín Sigurðardóttir (aks@hi.is) is a professor in educational leadership in School of Education, University of Iceland and coordinator for programme in educational leadership. She holds B.Ed. and M.Ed. in special education from Iceland University of Education. Her Ph.D. is from the University of Exeter in educational leadership. Research interest include educational leadership, school development, professional learning community and physical learning environment in relation with educational practices.

Sigrún Harpa Magnúsdóttir (sigrun.harpa.magnusdottir@reykjavik.is) is a project manager at the Reykjavik Department of Education and Youth. She completed a B.Ed. from The Iceland University of Education, diploma degree in project manager from University of Lillebælt in Denmark in 2006 and M.Ed. in Educational Studies from The University of Iceland in 2015. Her main project at the Department of Education and Youth are evaluation of compulsory schools and after school activity and youth centres in Reykjavik.

\section{Heimildir}

Alterator, S. og Deed, C. (2013). Teacher adaptation to open learning spaces. Issues in Educational Research, 23(3), 315-330.

Anna Kristín Sigurðardóttir. (2007). Próun einstaklingsmiðaðs náms í grunnskólum Reykjavíkur. Netla Veftímarit um uppeldi og menntun. Sótt af http://netla.khi.is/greinar/2007/012/index.htm

Anna Kristín Sigurðardóttir. (2014). Námsumhverfi í grunnskólum. Í Gerður G. Óskarsdóttir (ritstjóri), Starfshattir í grunnskólum við upphaf 21. aldar (bls. 57-83). Reykjavík: Háskólaútgáfan.

Anna Kristín Sigurðardóttir. (2018). Student-centred classroom environments in upper secondary school: Students' ideas about good spaces for learning vs. actual arrangements. Í L. Benade og M.Jackson (ritstjórar), Transforming education: Design E governance in global contexts (bls. 183-197). doi:10.1007/978-981-10-5678-9

Anna Kristín Sigurðardóttir og Torfi Hjartarson. (2016). The idea and reality of an innovative school. From inventive design to established practice in a new school building. Improving schools, 19(1), 62-79. doi:10.1177/1365480215612173 
Barrett, P., Zhang,Y., Moffat, J., og Kobbacy, K. (2013). A holistic, multi-level analysis identifying the impact of classroom design on pupils' learning. Building and Environment 59, 678-689. doi.10.1016/j.buildenv.2012.09.016

Benade, L. (2015). Teachers' critical reflective practice in the context of twenty-first century learning. Open review of Educational Research, 2(1), 42-54. doi:10.1080/23265507.2014.998159

Blackmore, J., Bateman, D., Loughlin. J., O’Mara, J. og Aranda, G. (2011). Research into the connections between built learning spaces and student learning outcomes: A literature review. Melbourne: State ofVictoria (Department of Education and Early Childhood Development).

Clark, J. (2012). Using diamond ranking as visual cues to engage young people in the research process. Qualitative Research Journal, 12(2), 222-237. doi.10.1108/14439881211248365

Clark, J., Laing, K., Tiplady, L. og Woolner, P. (2013). Diamond ranking activity. Making connections: Theory and practice of using visual methods to aid participation in research. Newcastle: Research Centre for Learning and Teaching, Newcastle University.

Dane, J. (2016). The effective teaching and learning spatial framework. Í W. Imms, B. Cleveland og K. Fisher (ritstjórar), Evaluating learning environments. Snapshots of emerging issues, methods and knowledge (bls. 211-230). Rotterdam: Sense Publishers.

Fredricks, J. A., Blumenfeld, P. C. og Paris, A. H. (2004). School engagement: Potential of the concept, state of the evidence. Review of Educational Research, 74(1), 59-109.

Fullan, M. (2016). The new meaning of educational change (5. útgáfa). New York: Teachers College Press.

Gerður G. Óskarsdóttir. (2012). Skil skólastiga. Frá leikskóla til grunnskóla og grunnskóla til framhaldsskóla. Reykjavík: Skóla- og frístundasvið Reykjavíkurborgar og Háskólaútgáfan.

Gerður G. Óskarsdóttir (ritstjóri). (2014). Starfshattir í grunnskólum við upphaf 21. aldar. Reykjavík: Háskólaútgáfan.

Gislason, N. (2010). Architectural design and the learning environment: A framework for school design research. Learning Environment Research, 13, 127-145.

Greene, B. A., Miller, R. B., Crowson, H. M., Duke, B. L. og Akey, K. L. (2004). Predicting high school students' cognitive engagement and achievement: Contribution of classroom perceptions and motivation. Contemporary Educational Psychology, 29, 462-482.

Imms, W., Cleveland, B. og Fisher, K. (ritstjórar). (2016). Evaluating learning environments. Snapshots of emerging issues, methods and knowledge. Rotterdam: Sense Publishers.

Ingvar Sigurgeirsson. (2005). Um einstaklingsmiðað nám, opinn skóla og enn fleiri hugtök ... Uppeldi og menntun, 14(2), 9-32.

Ingvar Sigurgeirsson, Arnór Benónýsson, Hallur Birkir Reynisson, Jóhanna Eydís Dórarinsdóttir ogValgerður Gunnarsdóttir. (2008) „Баð kemur ekki til greina að fara til baka“ Sveigjanlegt námsumhverfi í Framhaldsskólanum á Laugum. Netla-Veftímarit um uppeldi og menntun. Sótt af http://netla.hi.is/greinar/2008/003/ index.htm

Kanevsky, L., og Keighley,T. (2003). On gifted students in school:To produce or not to produce? Understanding boredom and the honour in underachievement. Roeper Review, 26(1), 20-28. doi:10.1080/02783190309554235

Kristjana Stella Blöndal og Sigrún Aðalbjarnardóttir. (2012). Student disengagement in relation to expected and unexpected educational pathways. Scandinavian Journal of Educational Research, 56(1), 85-100. doi:10 $.1080 / 00313831.2011 .568607$

Land, S., Hannafin, M. J., og Oliver, K. (2012). Student-centered learning environments: Foundations, assumptions and design. Í D. Jonassen og S. Land (ritstjórar), Theoretical foundations of learning environments (2. útgáfa) (bls. 3-25). New York og London: Routledge.

Lög um framhaldsskóla nr. 92/2008.

Markus, T. (1993). Buildings and power: Freedom and control in the origin of modern building types. London: Routledge. Mennta- og menningarmálaráđuneytið. (2014). Hvítbók um umbetur í menntun. Reykjavík: Höfundur.

Moore-Russo, D.,Viglietti,J. M., Chiu, M. M. og Bateman, S. M. (2013).Teachers' spatial literacy as visualization, reasoning, and communication. Teaching and Teacher Education, 29, 97-109. doi.10.1016/j.tate.2012.08.012 
Mulcahy, D., Cleveland, B. og Aberton, H. (2015). Learning spaces and pedagogic change: Envisioned, enacted and experienced. Pedagogy, Culture \& Society, 23(4), 575-595. doi:10.1080/14681366.2015.1055128

Norlander, P. (2014). Spaces and places for school-related learning: Challenges to the classroom. Í C. Burke, I. Grosvenor og B. Norlin (ritstjórar), Engaging with educational space. Visualizing spaces of teaching and learning (bls. 148-157). Umeå: Department of Historical and Religious Studies.

OECD. (2013). Innovative learning environments. doi:10.1787/9789264203488-en

Prain,V., Cox, P., Deed, C., Edwards, D., Farrelly, C., Keefe, M., ...Waldrip, B. (ritstjórar). (2015). Personalising learning in open-plan schools. Rotterdam: Sense Publishers.

Rúnar Sigpórsson, Anna-Lind Pétursdóttir og Póra Björk Jónsdóttir. (2014). Nám, pátttaka og samskipti nemenda. Í Gerður G. Óskarsdóttir (ritstjóri), Starfshœettir í grunnskólum við upphaf 21. aldar (bls. 161-196). Reykjavík: Háskólaútgáfan.

Smit, K., Brabander, C. J. og Martens, R. L. (2014). Student-centred and teacher-centred learning environment in pre-vocational secondary education: Psychological needs, and motivation. Scandinavian Journal of Educational Research, 58(6), 695-712. doi:10.1080/00313831.2013.821090

Tanner, C. K. (2008). Explaining the relationships among student outcomes and the school's physical environment. Journal of Advanced Academics, 19(3), 444-471.

Veloso, L., Marques, J. S. og Duarte, A. (2015). Changing education through learning spaces: Impacts of the Portuguese school buildings' renovation programme. Cambridge Journal of Education, 44(3), 401-423. doi :10.1080/0305764X.2014.921280

Woolner, P., McCarter, S., Wall, K. og Higgins, S. (2012). Changed learning through changed space: When can a participatory approach to the learning environment challenge preconceptions and alter practice? Improving Schools, 15, 45-60. doi:10.1177/1365480211434796

Duríður Jóna Jóhannsdóttir. (2017). Skólalíkan sem stuðlar að jafnrétti til náms: Einkenni skólastarfs við Menntaskólann á Tröllaskaga í ljósi kenninga Bernsteins. Netla - Veftímarit um uppeldi og menntun. Sótt af http://netla.hi.is/greinar/2017/ryn/15.pdf

Anna Kristín Sigurðardóttir og Sigrún Harpa Magnúsdóttir. (2018).

Nemendamiðað námsumhverfi: Hugmyndir framhaldsskólanemenda um kjöraðstæður til náms.

Netla - veftímarit um uppeldi og menntun. Sérrit 2018 - Framhaldsskólinn í brennidepli.

Sótt af http://netla.hi.is/serrit/2018/framhaldskolinn_brennidepli/02.pdf

DOI: https://doi.org/10.24270/serritnetla.2019.2 